

\section{DISCLAIMER}

This report was prepared as an account of work sponsored by an agency of the United States Government. Neither the United States Government nor any agency Thereof, nor any of their employees, makes any warranty, express or implied, or assumes any legal liability or responsibility for the accuracy, completeness, or usefulness of any information, apparatus, product, or process disclosed, or represents that its use would not infringe privately owned rights. Reference herein to any specific commercial product, process, or service by trade name, trademark, manufacturer, or otherwise does not necessarily constitute or imply its endorsement, recommendation, or favoring by the United States Government or any agency thereof. The views and opinions of authors expressed herein do not necessarily state or reflect those of the United States Government or any agency thereof. 


\section{DISCLAIMER}

Portions of this document may be illegible in electronic image products. Images are produced from the best available original document. 


\title{
Suitability of Tophet C-Alloy 52/Kovar Components to Hydrogen Environments
}

\author{
James M. Gebhart and Michael D. Kelly
}

Issued: June 22, 1976

\section{NOTICE}

This report was prepared as an account of work sponsored by the United States Government. Neither the United States nor the United States Energy Research and Development Administration, nor any of their employees, nor any of their contractors, subcontractors, or their employees, makes any warranty, express or implied, or assumes any legal liability or responsibility for the accuracy, com-

pleteness or usefulness of any information, apparatus, product or process disclosed or represents that its use would not infringe privately owned rights.

PRINTED IN THE UNITED STATES OF AMERICA

Available from

National Technical information Service

U. S. Bepartment of Commerce

52R5 Port Roval Road

Springfield, Virginia 22161

Price: Printed Copy \$4.00; Microfiche $\$ 2.25$

\section{MONSANTO RESEARCH CORPORATION}

A Subsidiary of Monsanto Company

\section{MOUND IABORATORY}

Miamisburg, Ohio

45342

operated for

\section{UNITED STATFS ENERGY RESEARCH AND DEVELOPMENT ADMINISTRATION}

U. S. Government Contract No. E-33-1-GEN-53 


\begin{abstract}
The suitability of Tophet C-Alloy 52/Kovar weldments to hydrogen embrittlement were investigated because of their potential as candidate materials in fabrication of minaturized initiators for pyrotechnics. Cathodic charged samples were statically loaded for extended periods of time resulting in no load failures and in ductile fracture surfaces indicating resistance to hydrogen embrittlement.
\end{abstract}




\section{Introduction}

The metallurgical literature has no specific references concerning the susceptibility to hydrogen embrittlement of Tophet $C$ welded to Kovar or to Alloy 52 . To ascertain the expected satisfactory behavior of these materials, a test matrix was developed using Kovar and Alloy 52 in conjunction with Tophet $C$. These are potential candidate materials for electrode (Kovar or Alloy 52) and.bridgewire (Tophet C) to be used in the fabrication of miniaturized initiators for pyrotechnics. The testing method involved staticload testing of parent material and of hydrogen-charged material. The mechanism for hydrogen embrittlement is time dependent; therefore, if hydrogen embrittlement occurs, the plot of load as a function of time to failure is typically an S-shaped curve. Example curves of hydrogen embrittlement are shown in Figure 1. Fracture surfaces were analyzed with the Scanning Electron Microscope (SEM) to cumplement the data from the load tests. Examination was for minute areas of hydrogen embrittlement which would be obscured by variations in the load test.

\section{Experimental}

Two sample sizes were used for the static load test because initially only a 2-mil Tophet $C$ wire was available. The size of the wire and methods available for obtaining a reproducible weld limited the sample configuration. Sample geometries-were not of the usual static load configuration but were selected to duplicate anticipated product design. Figure 2 is a schematic depicting the static load test configuration. The Kovar or Alloy 52 was held in a horizontal position by a pin vise, and the vertical Tophet $C$ wire, which had been welded to the horizontal member, was statically loaded. Table 1 lists the combinations of wire sizes used. One set of samples was resistance welded; the other set was laser welded. A typical resistance weld is shown in Figure 3 , and a laser weld in shown in Figure 4.. Instron tests of samples showed that the weld configurations would fail at uniform load values. Thig small scatter in break strength provided a high degree of confidence in data for samples load tested at slightly below the failure values.
Thermal charging of samples resulted in excessive surface reaction. The reaction was due to gross contamination of the furnace atmosphere. With some modification, the problem could have been eliminated. However, cathodic charging was easily accomplished with very little preparation of equipment.

After the wires were welded, cathodic charging of hydrogen was accomplished with a $1 \mathrm{~N}_{2} \mathrm{HO}_{4}$ solution poisoned with sodium arsenite $(250 \mathrm{mg} / \mathrm{l})$ using a platinum anode and a current density of $0.5 \mathrm{~A} / \mathrm{cm}^{2}$. The samples were electropolished in the solution for $30 \mathrm{sec}$ prior to charging to remove possible inhibiting surface films. The sample polarity was reversed after electropolishing without removing the samples from the solution, and the samples were charged for $4 \mathrm{hr}$. The samples were analyzed for hydrogen by the fusion method with a Leco $\mathrm{R}-\mathrm{H}-4$ Hydrogen Deteruinator. Results of the hydrogen analyses are given in Table 1 . 


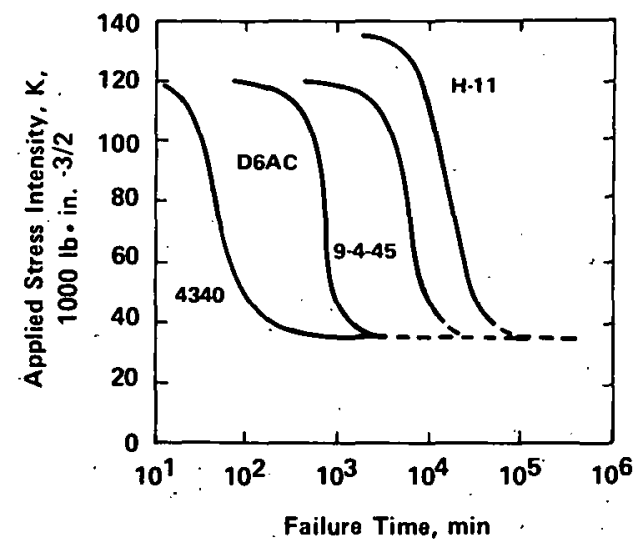

FIGURE 1 - Effect of applied stress intensity on

time to failure. for commercial high strength steel.

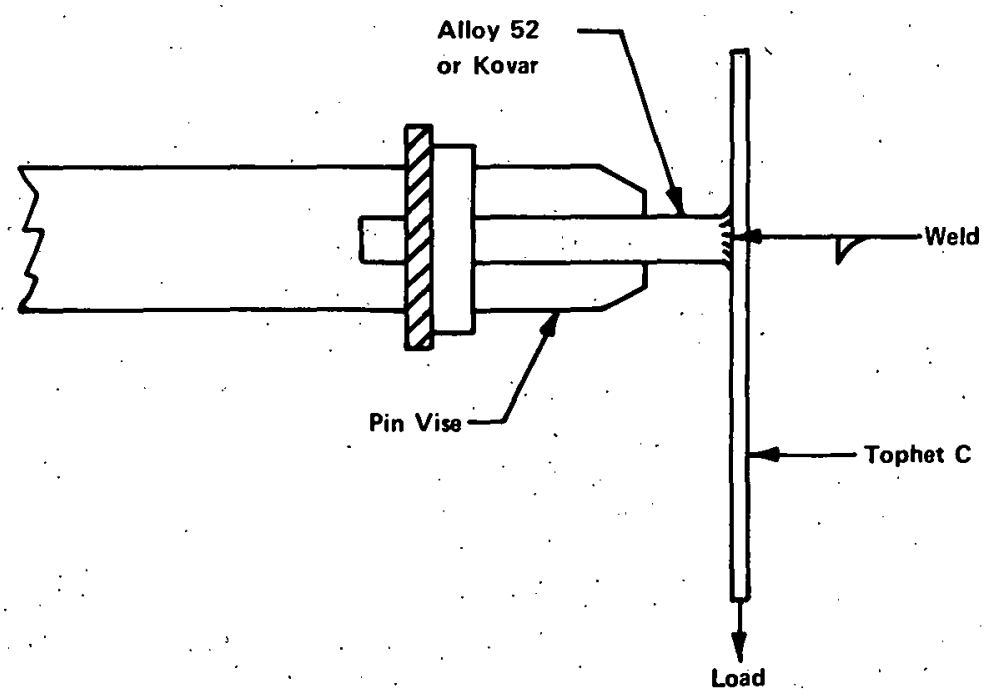

FIGURE 2. - Schematic of static load test.

Table 1 .

STATIC LOAD TEST TO EVALUATE HYDROGEN EMBRITTLEMENT

\begin{tabular}{|c|c|c|c|c|c|c|c|}
\hline & Materials & Weld Type & $\begin{array}{c}\text { Break } \\
\text { Strength } \\
(\mathrm{kg}) \\
\end{array}$ & $\frac{\text { Hydro }}{\text { Alloy }}$ & $\begin{array}{c}\text { gen Conte } \\
52 / \text { Kovar }\end{array}$ & $\frac{\text { nt (ppm) }}{\text { Tophet C }}$ & $\begin{array}{c}\text { Load Applied } \\
(\mathrm{kg})\end{array}$ \\
\hline $35-\mathrm{mil}$ & Kovar + 2-mil Tophet $\mathrm{C}$ & Resistance & 00.195 & & 15.0 & 100.0 & $0.126-0.166$ \\
\hline $35-\mathrm{mil}$ & Alloy $52+2-\mathrm{mil}$ Tophet C & Resistance & 00.200 & . & 15.0 & 100.0 & $0.126-0.166$ \\
\hline $50-\mathrm{mil}$ & Kovar $+38-\mathrm{mil}$ Tophet $\mathrm{C}$ & Laser & 22.700 & & 16.3 & 14.3 & $17.7-20.5$ \\
\hline $50-\mathrm{mil}$ & Alloy $52+38-\mathrm{mil}$ Tophet $\mathrm{C}$ & Laser & 24.970 & 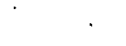 & 7.6 & 14.3 & $17.7-20.5$ \\
\hline
\end{tabular}




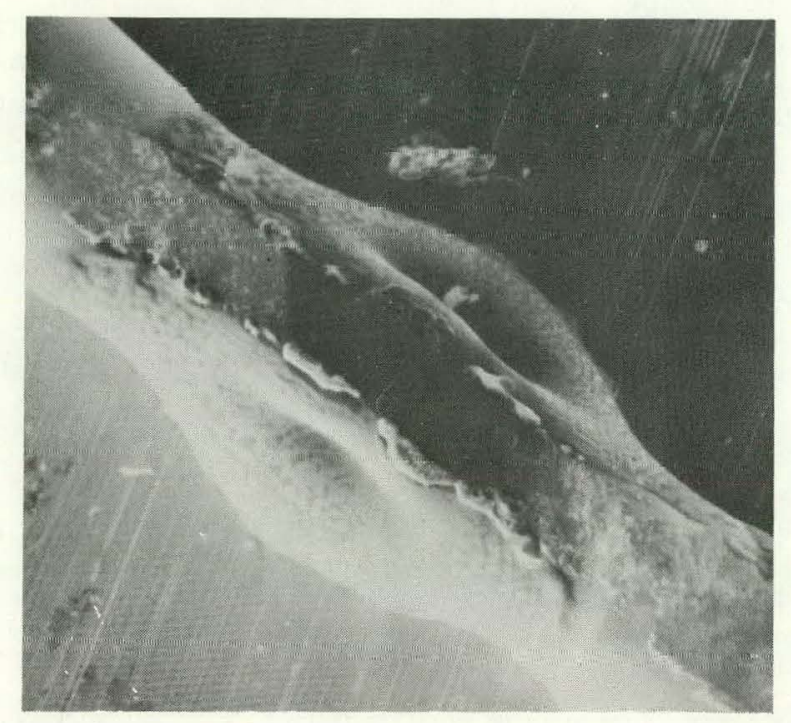

FIGURE 3 - SEM SCan of 2-mil Tophet $C$ resistance welded to 35-mil Kovar, $720 x$. (Reduced to $80 \%$ for reproduction.)

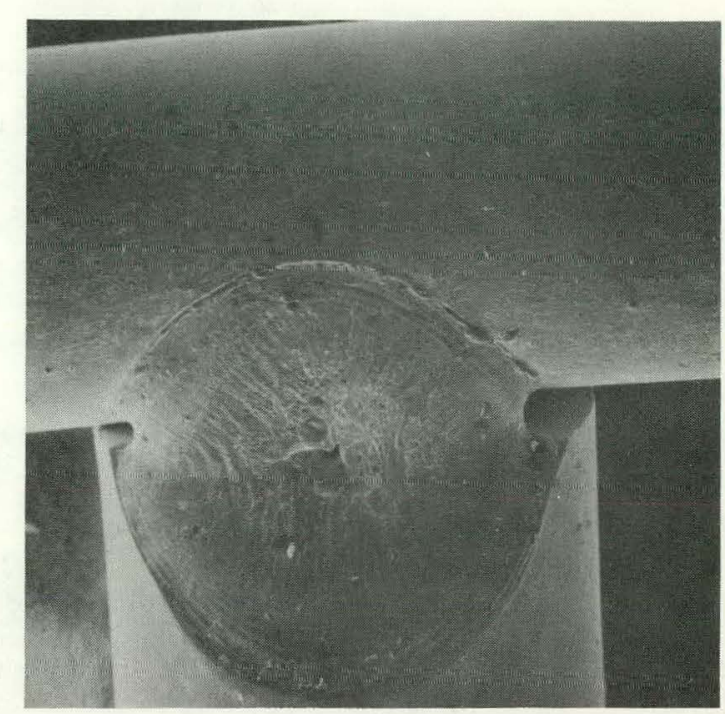

FIGURE 4 - SEM sCan of 38-mil Tophet C laser welded to 50-mil Kovar, $40 \mathrm{X}$. (Reduced to $80 \%$ for reproduction.)

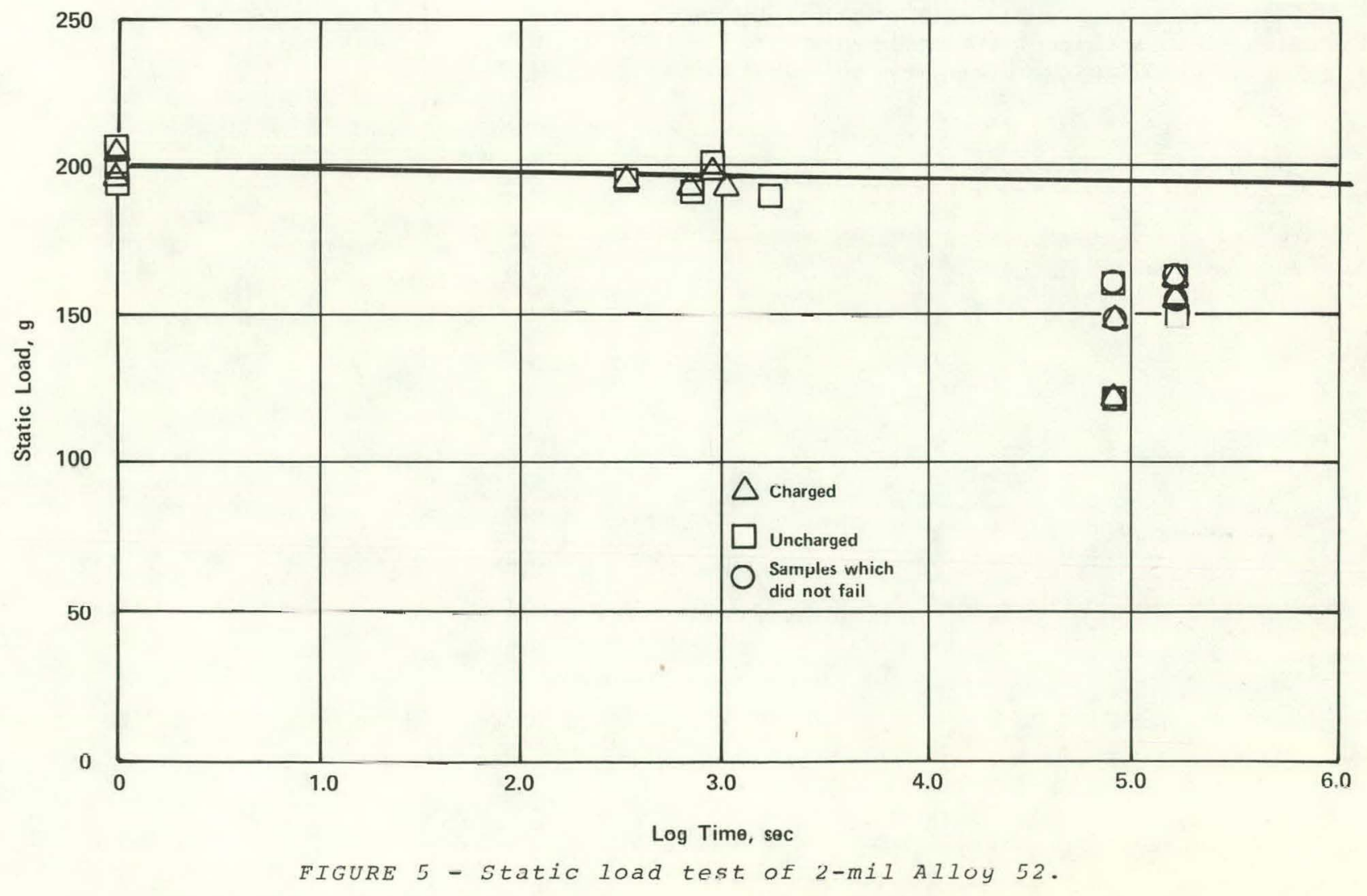




\section{Results}

Indication of hydrogen embrittlement would be an S-shaped curve when static load test data are plotted. This curve would be similar to the curve shown previously in Figure 1. The static load test data for the systems under consideration are plotted in Figures 5 through 8. The load at failure was plotted as a function of log of time to fail and resulted in a straight line relationship. Neither the charged nor uncharged samples deviated from this straight line. Samples tested at 80 to 95\% of the breaking load did not fail under long-term testing.

Slight variations in test sample geometries caused some scatter in the data. Although this scatter is slightly larger than that normally seen in static load tests, it is not considered enough to obscure indications of embrittlement. Increased scatter was considered insignificant compared to the value of using test samples with the finished product configuration. The straight-line relationships resulting from the failures and from the no failures at reduced load for extended periods of time are considered to be reasonable indications of resistance to hydrogen embrittlement.

No evidence of microcracking was present on the external surface of the samples after charging. Representative SEM micrographs of the fracture surfaces are presented in Figures 9 through 20. The surfaces were comprised entirely of tensile and shear dimples indicating ductile fractures. No features of hydrogen-embrittled fractures were found in any of the test samples.

\section{Conclusions}

It is believed resistance to hydrogen embrittlement has been demonstrated by the linear relationship between load at failure as a function of time, by the samples not failing at reduced load for extended periods of time, and by the ductile fracture surfaces. 


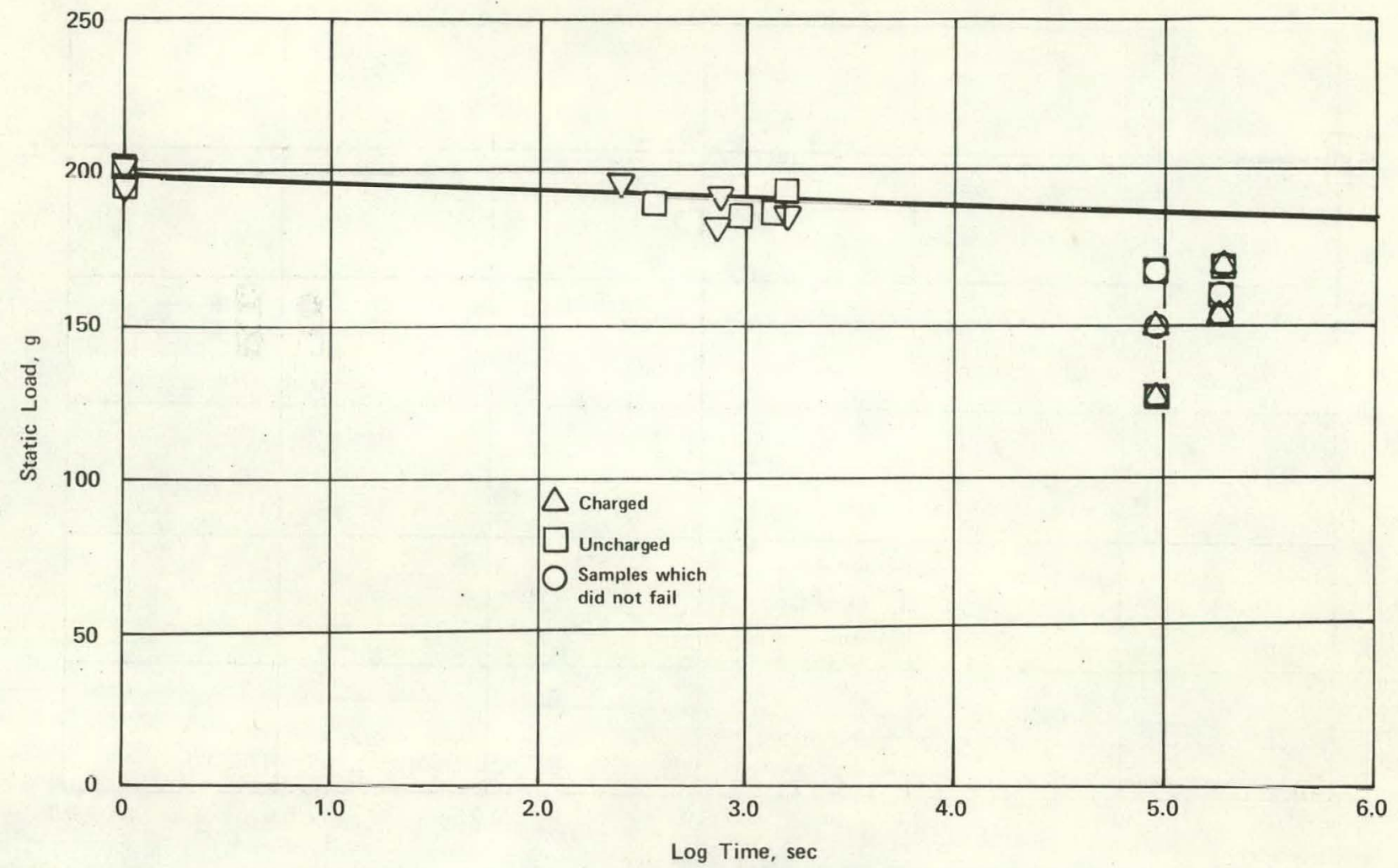

FIGURE 6 - Static load tost of 2-mil Tophet C/Kovar.

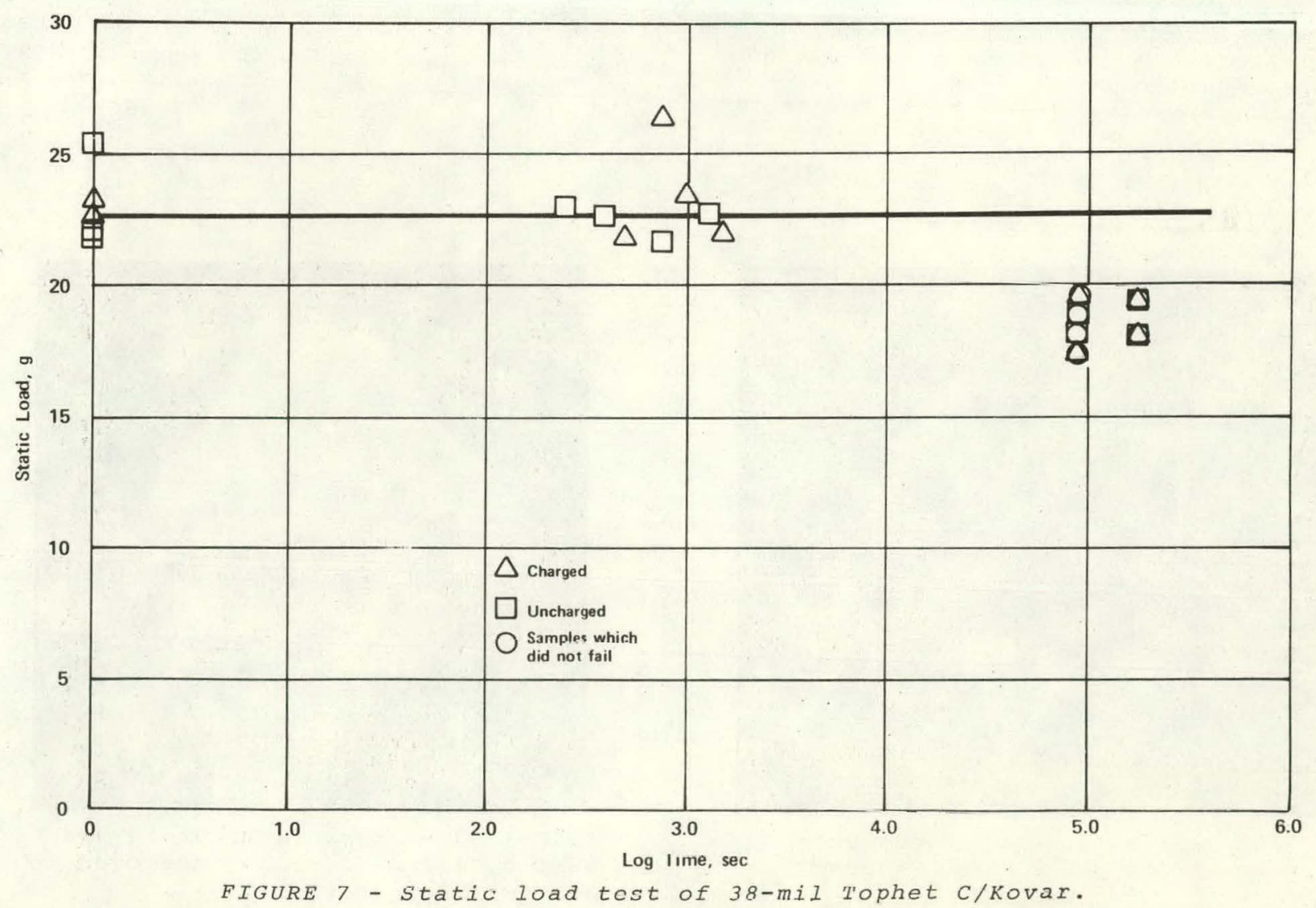




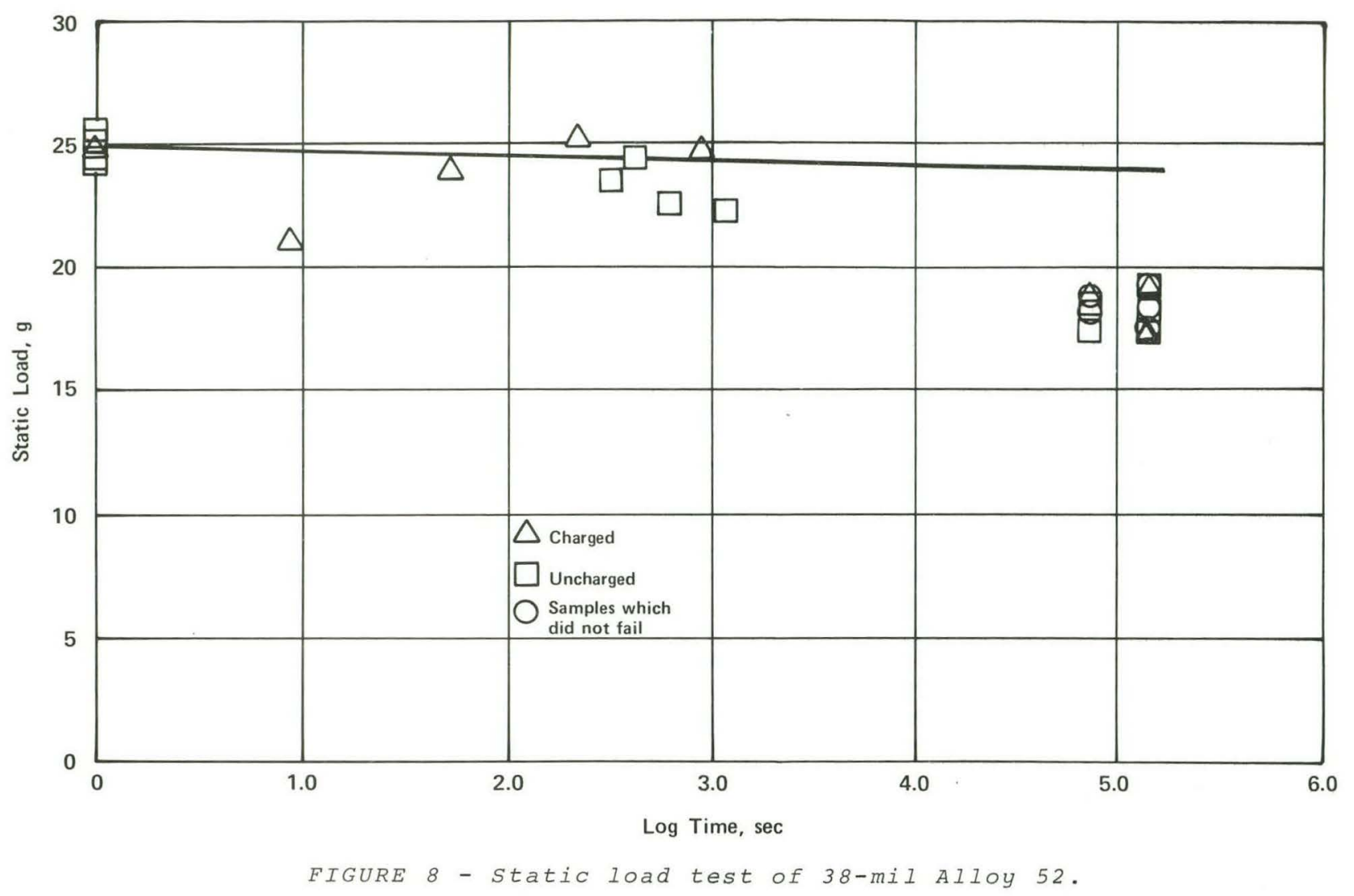

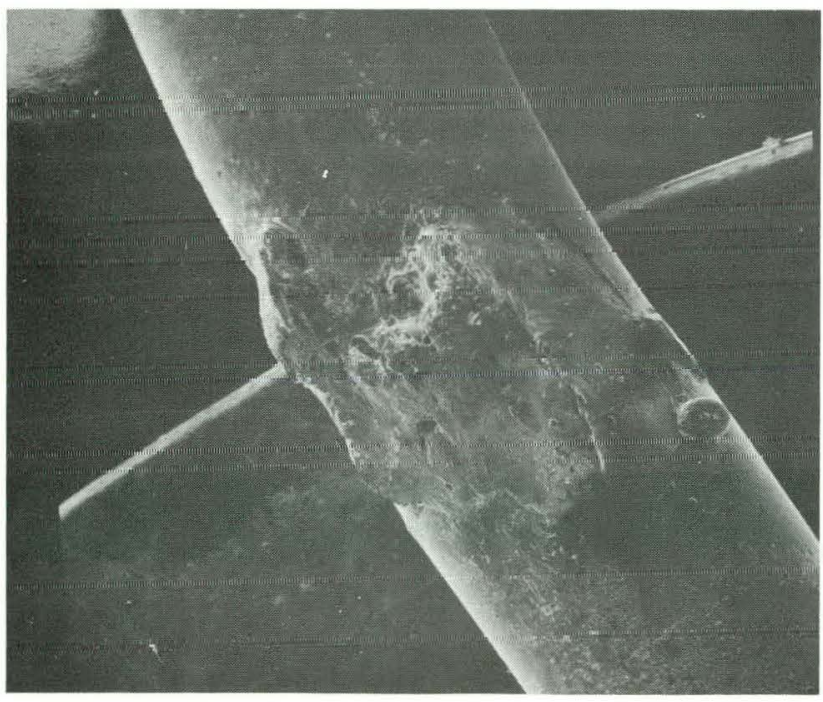

FIGURE 9 - Fracture of uncharged sample, Tophet $C, 30 X$. (Reduced to $80 \%$ for reproduction.)

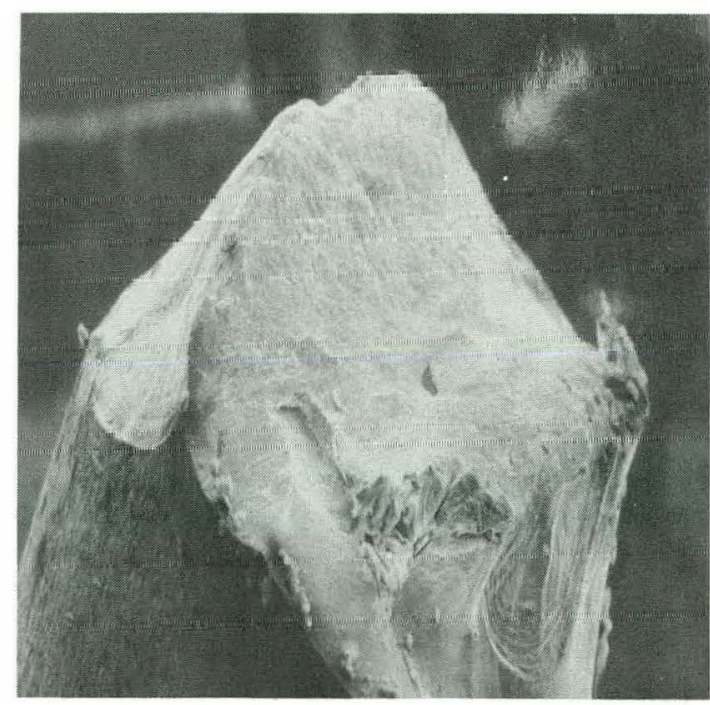

FIGURE 10 - Fracture of uncharged sample, Alloy 52, 50x. (Reduced to $80 \%$ for reproduction.) 


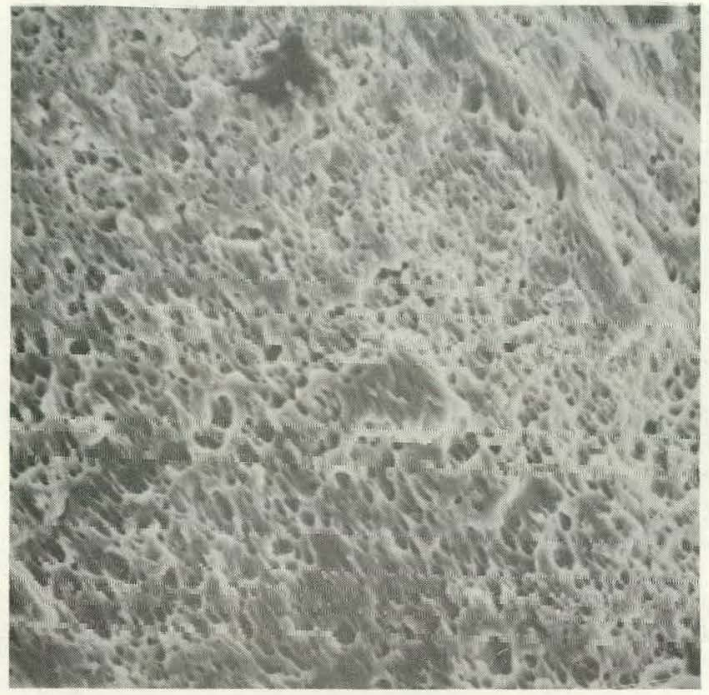

FIGURE 11 - Fracture surface of uncharged Alloy 52 sample showing shear dimples, $2000 x$. (Reduced to $80 \%$ for reproduction.)

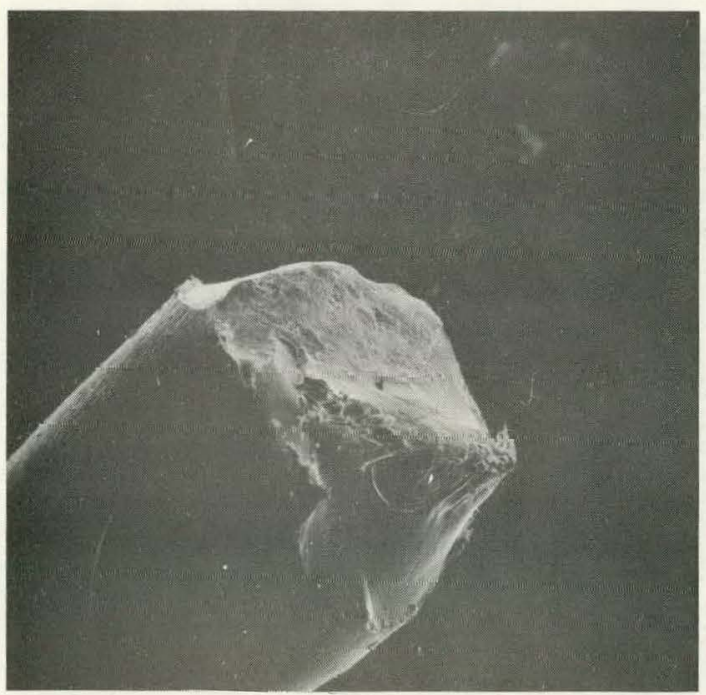

FIGURE 13 - Fracture of Tophet C wire which had been welded to Kovar and charged, 30x. (Reduced to $80 \%$ for reproduction.)

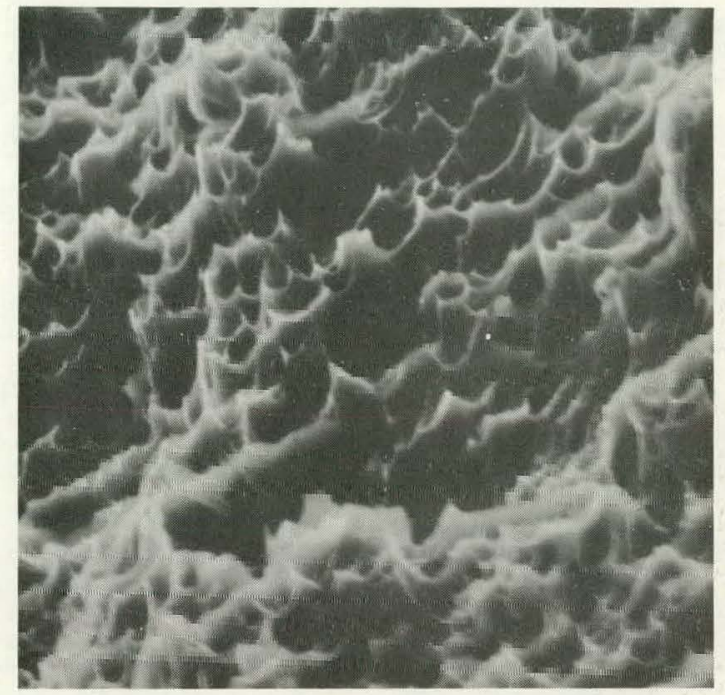

FIGURE 12 - Fracture surface of uncharged Alloy 52 sample showing tensile dimples, $5000 x$. (Reduced to $80 \%$ for reproduction.)

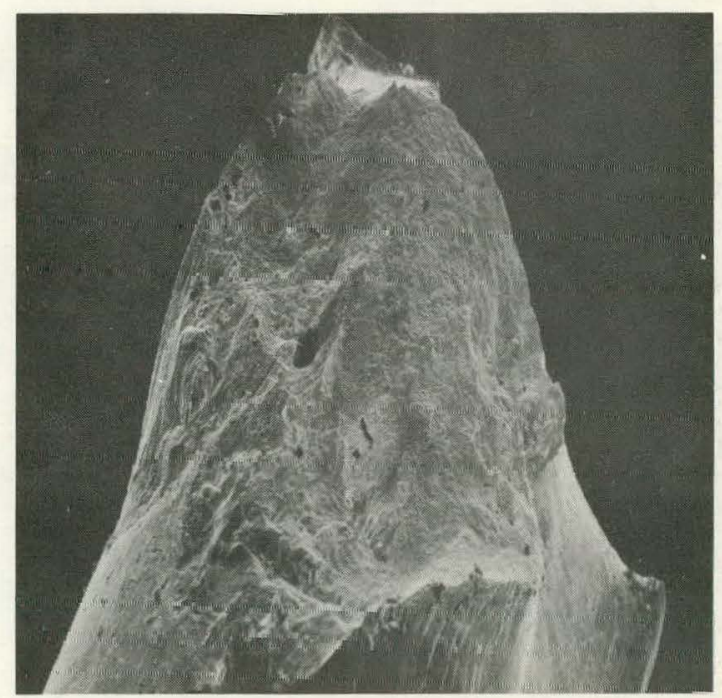

FIGURE 14 - Fracture of Kovar which had been welded to Tophet $C$ and charqed, $50 x$. (Reduced to $80 \%$ for reproduction.) 


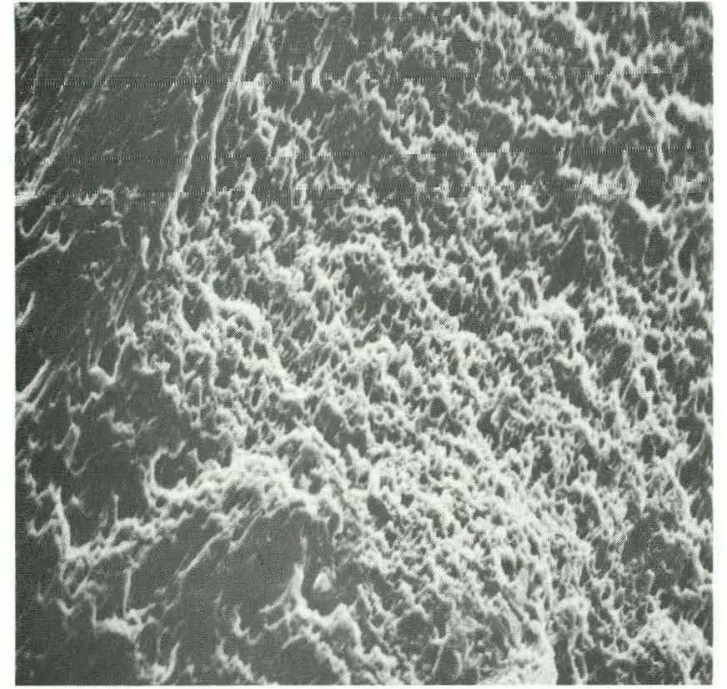

FIGURE 15 - Fracture surface of charged Kovar wire containing shear and tensile dimples, looox. (Reduced to $80 \%$ for reproduction.)

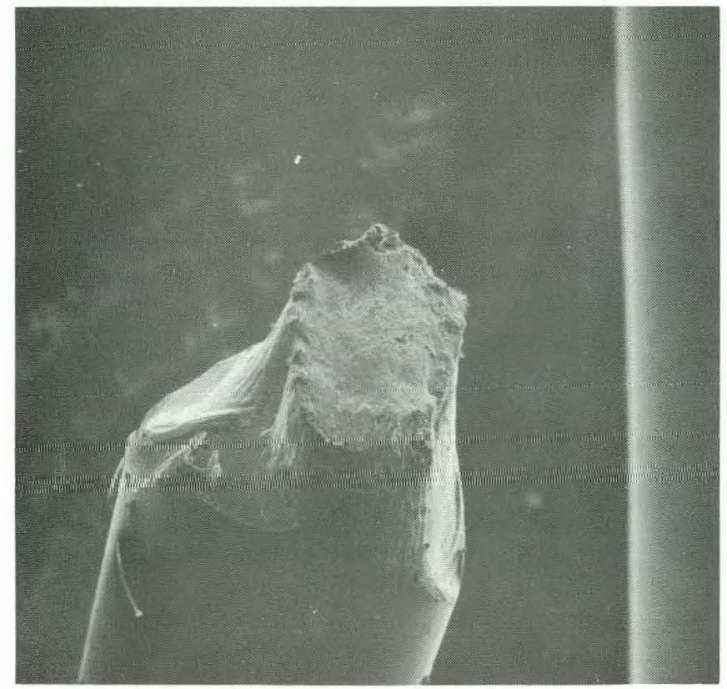

FIGURE 17 - Fracture of Alloy 52 wire which had been welded to Tophet $C$ and charged, $30 x$. (Reduced to $80 \%$ for reproduction.)

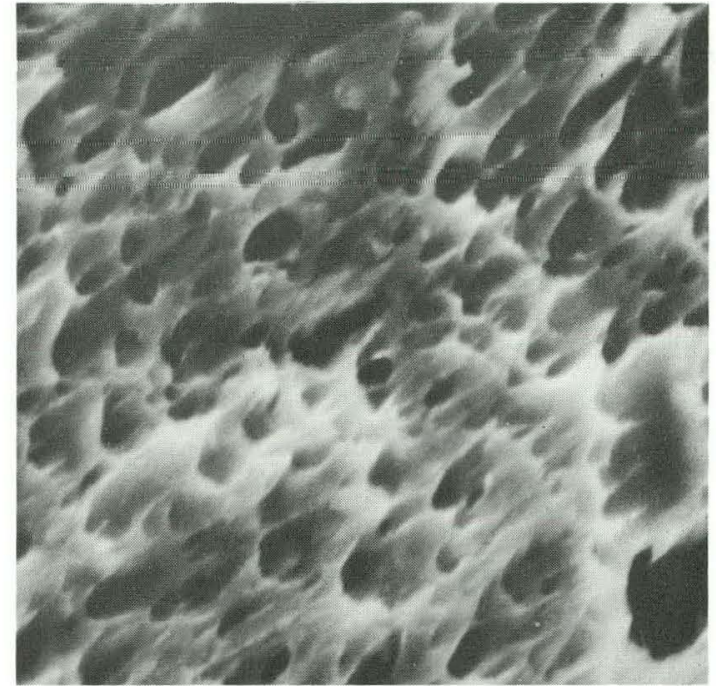

FIGURE 16 - Fracture surface of charged Kovar wire showing tensile dimples, $5000 x$. (Reduced to $80 \%$ for reproduction.)

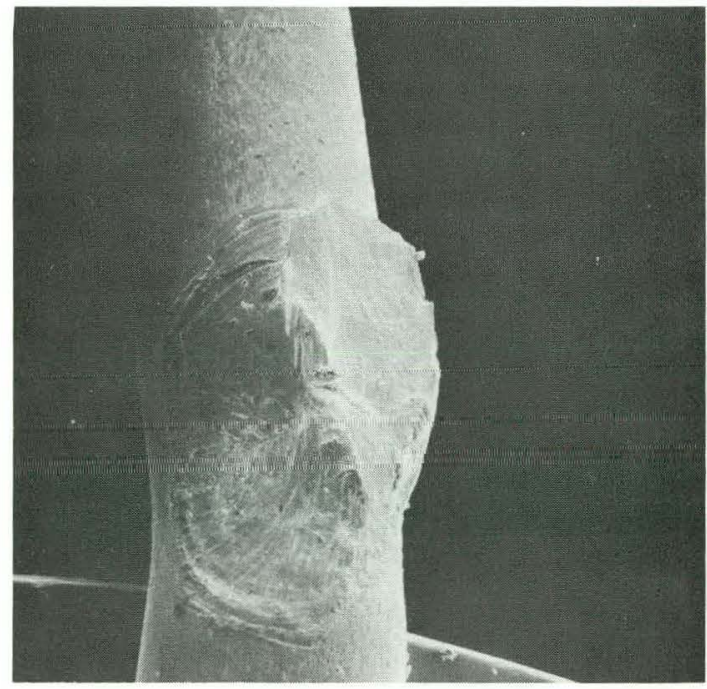

FIGURE 18 - Fracture of Tophet $C$ which had been welded to Alloy 52 and charged, $30 x$. (Reduced to $80 \%$ for reproduction.) 


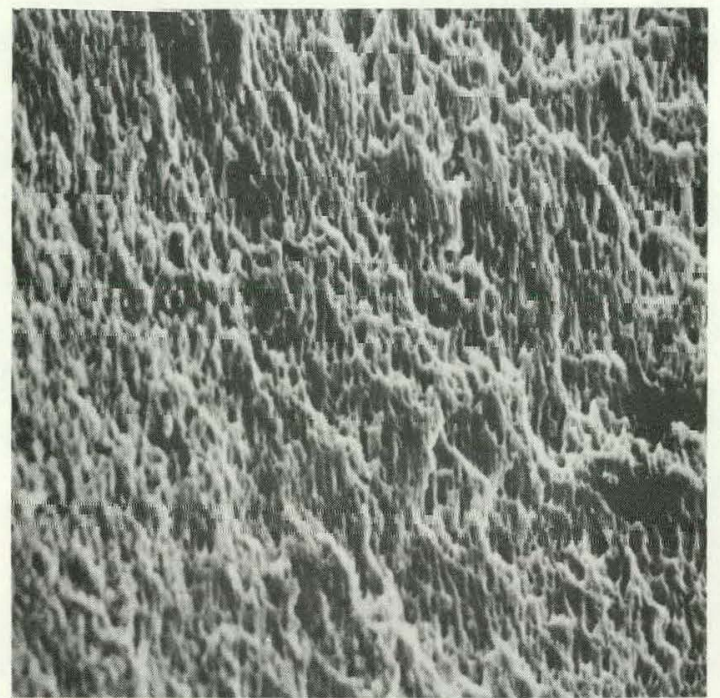

FIGURE 19 - Fracture surfacc of charged Tophet $C$ wire containing shear dimples, $1000 x$. (Reduced to $80 \%$ for reproduction.)

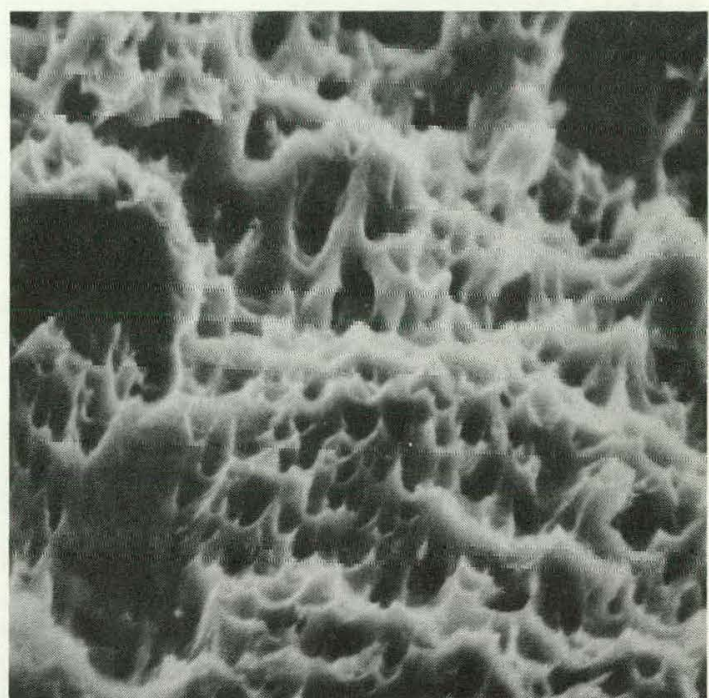

FIGURE 20 - Fracture surface of charged Alloy 52 wire containing tensile dimples, $5000 x$. (Reduced to $80 \%$ for reproduction.)

REFERENCE

1. W. W. Gerberich, "Effect of Hydrogen on High Strength and Martensitic Steels," in Hydrogen in Metals, J. M. Bernstein and A. W. Thompson (ed.), American Society for Metals, 1974, p. 116. 


\section{Distribution}

EXTERNAL

TID-4500, UC-25 (197)

Consultants

C. F. Curtiss

University of Wisconsin

C. F. Eck

Miamisburg, Ohio

D. F. Griffing

Miami University

J. H. Leonard

University of Kentucky

R. E. Miers

Ft. Wayne, Indiana

W. E. Moddeman

University of Dayton Research Institute

G. W. Powell

Ohio State University

A. Shapiro

University of Cincinnati

H. F. Swift

University of Dayton Research Institute

D. White

University of Pennsylvania

H. W. Mattson, Monsanto Company

J. A. Chacon, DAO

R. K. Flitcraft, MRC

\section{INTERNAL}

J. E. Bradley

J. R. Brinkman

W. T. Cave

R. A. Fischbein

J. M. Gebhart (2)

L. D. Haws

C. W. Huntington

R. F. Ivory

L. V. Jones

D. P. Kelly

M. D. Kelly (2)

F. D. Lonadier

W. J. Murphy

W. H. Smith

P. A. Tucker

H. L. Turner

R. E. Vallee

Publications

Library (15) 